\title{
THE INFLUENCE OF ORGANIZATIONAL FORM AND CUSTOMER TYPE ON ONLINE CUSTOMER SATISFACTION RATINGS
}

\section{Introduction}

The plural form in franchising, involving the coexistence of company-owned units and franchised units within a same chain, is a topic of great interest to researchers examining small business management and entrepreneurship (Brand and Croonen 2010; Castrogiovanni, Combs, and Justis 2006; Dant, Perrigot, and Cliquet 2008). Many studies on plural form have been carried out at the chain level. For instance, researchers have focused on the synergistic effects of having company-owned units and franchised units within the same chain (Bradach 1998; Meiseberg 2012). Other scholars have considered various chain characteristics as determinants of the proportion of company-owned units within the chain (Cliquet and Pénard 2012; Shane 1998). Still others have taken an alternative perspective, examining different consequences of the proportion of company-owned units within the chain on chain performance (Botti, Briec, and Cliquet 2009; El Akremi, Perrigot, and PiotLepetit forthcoming). Research has also examined the impact of plural form on strategies including internationalization (Elango 2007), E-commerce (Perrigot and Pénard 2013) and communication on social responsibility (Perrigot, Oxibar, and Dejean forthcoming). Recently, a few authors have highlighted some of the limits of this plural form in terms of network culture and cohesion, potential conflicts and cost issues (Perrigot and Herrbach 2012), and of non-reiteration of the benefits usually associated with the plural form in the context of international hotel chains (Brookes and Roper 2012).

Other studies on the plural form have been carried out at the unit level. Several authors have compared company-owned units and franchised units in terms of performance 
(Anderson 1984; Kosová, Lafontaine, and Perrigot 2013; Shelton 1967), health inspection ratings (Beheler, Norton, and Sen 2008), hygiene scores (Jin and Leslie 2009) and price (Kosová, Lafontaine, and Perrigot 2013). Findings of these studies have been mixed; for instance, Kosová, Lafontaine, and Perrigot (2013) found no statistically significant differences between company-owned hotels and franchised hotels in terms of total sales, RevPAR (revenue per available room) and price when controlling other hotel and market factors and endogenizing the choice of organizational form. These papers have mainly dealt with financial metrics such as pricing power, asset utilization and RevPAR (revenue per available room).

While some research has examined the influence of the percentage of companyowned versus franchised units on satisfaction at the chain level (Michael 2000; O'Neill, Mattila, and Xiao 2006), we are aware of no published paper that examines the potential differences between these two organizational forms in terms of customer satisfaction ratings at the unit level. In this paper, we address this gap by focusing on understanding the relationship between the organizational form of the unit (company-owned versus franchised) and customer satisfaction in the form of online ratings, by also taking into consideration the type of customer (non-business versus business). Specifically, we explore the following research questions:

(1) Do customers perceive any differences between company-owned units and franchised units within a given chain? If so, then which organizational form performs better in terms of satisfaction ratings?

(2) Are there any differences between satisfaction ratings of non-business customers and business customers? And, does the type of customer influence the relationship between organizational form of the unit and customer satisfaction? 
The choice to focus our empirical study on the hotel industry is driven by three main factors. First, franchising is particularly developed in the hotel industry (see Kehoe 1996). For instance, among the 2013 top 5 ranking of worldwide hotel groups, all groups use franchising to develop their brands (for instance, IHG, Hilton Hotels, Marriott International, Wyndham Hotel Group and Choice) (http://www.hospitalitynet.org/news/4060119.html and 2013 Franchise Times Top 200 Franchise Systems). Secondly, most franchisors in the hotel industry use the plural form (Botti, Briec, and Cliquet 2009; Chen and Dimou 2005; Kehoe 1996; Perrigot, Cliquet, and Piot-Lepetit 2009). For example, $41 \%$ of Hilton Hotels \& Resorts are franchised, $41 \%$ of Marriott Hotels, Resorts \& Suites are franchised and $48 \%$ of Sheraton Hotels \& Resorts are franchised (2013 Franchise Times Top 200 Franchise Systems). Third, the hotel industry has a robust set of review sites that are updated regularly by consumers. Our decision to focus on TripAdvisor as the source of consumer-generated ratings is mainly influenced by its size and dominance in the consumer review market.

Our empirical study deals with 6,348 TripAdvisor online consumer-generated reviews regarding stays at one of the 134 hotels of a plural form chain. These 134 hotels are all the hotels of this chain that are located in the domestic market of a Western European country. This chain is considered midscale, and its hotels are located in all regions of its domestic market. Among the 134 hotels, 93 are company-owned (69.40 percent) and 41 are franchised (30.60 percent). All the franchised hotels are operated by single-unit franchisees. For each hotel, we have its main characteristics (location, amenities, number of rooms); and for each customer, we have their profile (gender and type: non-business versus business) and satisfaction scores on multiple satisfaction criteria posted on TripAdvisor.

Our empirical findings yield important insights. First, we find that company-owned hotels outperform their franchised counterparts on customer satisfaction regarding hotel 
location. Second, business customers have lower satisfaction than non-business customers on all satisfaction measures. Lastly, though we find no consistent main effect of organizational form on satisfaction related to service, our results show that the type of customer (non-business versus business) moderates the relationship between organizational form and customer satisfaction. We find that business travelers have higher satisfaction with franchised hotels than company-owned hotels.

Our research contributes to the existing literature in several ways. First, this study contributes to the literature on plural form in franchising, and more specifically to the stream of literature dedicated to within-chain differences, that is, between company-owned units and franchised units. We also add to a stream of research examining the relationship between customer-level variables such as expertise (Anderson, Pearo, and Widener 2008; Czellar 2003; Jamal and Anastasiadou 2009; Reinartz and Kumar 2002; Walsh, Evanschitzky, and Wunderlich 2008) and their attitudes and behaviors. This research also enlarges the body of franchising literature dedicated to the hotel industry (Alon, $\mathrm{Ni}$, and Wang 2012; Botti, Briec, and Cliquet 2009; Brookes and Roper 2012; Chen and Dimou 2005; Dahlstrom et al. 2009; Perrigot, Cliquet, and Piot-Lepetit 2009). Finally, this paper responds to the call for more franchising research adopting a customer perspective (Dant, Grünhagen, and Windsperger 2011; Dant 2008) as well as for more franchising research on markets outside the US (Dant, Perrigot, and Cliquet 2008; Dant 2008).

The following description presents the manner in which this paper is organized. In the two next sections, we review the literature and develop our hypotheses. We then describe the methodology and present the findings of our empirical analyses. We finally discuss the theoretical contributions, managerial implications and limitations of our work and provide suggestions on topics for future research. 


\section{Literature Review}

The coexistence of the two organizational forms within the same chain, company ownership and franchising, is identified as a plural form. Bradach and Eccles (1989, p. 287) define plural form as "an arrangement where distinct organizational control mechanisms are operated simultaneously for the same function by the same firm." Almost all franchised chains include a certain number of company-owned units (Bradach and Eccles 1989; Kosová and Lafontaine 2012). Such an arrangement allows researchers to examine the potential differences in performance that may exist between company-owned units and franchised units within a single chain. These two types of relationships, one involving vertically-integrated units and the other a third party entity, give rise to complex contracting and incentive problems that have often been explored through the lens of agency theory (Brickley, Dark, and Weisbach 1991; Carney and Gedajlovic 1991; Combs and Ketchen 1999a; Lafontaine 1992; Shane 1996). Agency theory is a common and widely accepted theory for exploring incentive structures in channel relationships in both marketing (see Bergen, Dutta, and Walker 1992) and operations management (see Handley and Benton 2012). Agency theory is also a dominant theory in the study of franchising from various perspectives (Brickley and Dark 1987; Carney and Gedajlovic 1991; Combs and Ketchen 1999b, 2003; Fladmoe-Lindquist and Jacque 1995; Lafontaine 1992; Shane 1996, 1998). Risk sharing and moral hazard arguments have been used to explain the power of franchising through its ability to align the interests of franchisors and franchisees.

As residual claimants, franchisees are interested in maximizing return from owning and operating their individual local units. This incentive, theoretically, should drive franchisees to put forth different effort than managers of company-owned units, and thus lead to different levels of unit performance and subsequent customer satisfaction. 
Arguments can be made that franchisees, as residual claimants, are incentivized to work harder than managers of company-owned units; resulting in a customer experience of higher quality. However, we can also argue that franchisees, as part of a branded chain, could freeride on the brand and therefore lower quality and raise price, thus leading to a lower level of customer satisfaction. Since an individual franchisee is part of a chain of units, positive spillover (Brickley and Dark 1987) allows franchisees to free-ride on the franchisor's brand. Prior research has examined this issue of differential performance and findings have been mixed. We review literature in the following paragraphs.

The theoretical argument that franchisees will outperform managers of companyowned units stems from the following agency theoretic argument: franchising solves the inherent moral hazard of company-owned unit managers (Jensen and Meckling 1976). As mentioned earlier, agency theory supports the claim that franchisees have higher incentives to monitor their employees, as the owner-manager's wealth is highly dependent on the performance of its local unit. By incentivizing franchisees through residual profits, franchisors can reduce the potential costs incurred by corporate employees who need to be closely monitored (Rubin 1978).

Shelton (1967) was most likely the first researcher to study issues concerning the two organizational forms - company ownership and franchising in the restaurant industry. Even though he found that revenues did not significantly vary between the two organizational forms, he argued that costs were higher and consequently profits were lower in companyowned units compared to franchised units.

Beheler, Norton, and Sen (2008) examined performance differences between company-owned and franchised units in the US fast food industry. They concluded that franchised units had significantly higher ratings in health inspections, thus supporting the 
idea that operational standards are not only higher in franchised units but also that operational standards are more consistent than in company-owned units. Krueger (1991) provides further credibility to this argument, finding that the differential impact of contractual arrangements gives managers of company-owned units less incentive to monitor and supervise their employees. His findings were recently supported by Freedman and Kosová (forthcoming) who found that differences in wages and human resource practices support the agency theoretic argument that franchisees monitor their employees more closely than managers of company-owned units.

In addition to supporting the superior performance of franchised units, agency theory can be used to make the argument that company-owned units will outperform franchised units. Such arguments result from the fact that franchisees share the brand with other stakeholders, and therefore may be motivated to cut costs and free-ride on the brand. As one of many stakeholders of the brand, franchisees do not bear the full cost of customer satisfaction since these costs are shared by the franchisor and other franchisees within the chain (Caves and Murphy 1976; Lafontaine and Shaw 2005). Without sufficient monitoring, franchisees would be expected to cut costs at their unit resulting in lower quality ratings than at company-owned units. Michael (2000) supports such an argument by finding lower Consumer Reports quality ratings for predominantly franchised chains, in both the restaurant and hotel industries. Further evidence of franchisee free-riding is provided by Jin and Leslie (2009) who found that hygiene scores were higher in company-owned restaurants than in franchised restaurants within a same chain.

Anderson (1984) studied the performance of company-owned units and franchised units in 17 business areas. For eleven out of 17 business areas, he found performance differences between the two organizational forms. In seven out of these eleven business 
areas, company ownership showed a faster increase in average sales than franchising did. Nevertheless, the reason for the cases in which franchised units outperform company-owned units in certain business areas was attributed to advantageous locations.

Although research has supported outcomes consistent with higher performance of both company-owned units and franchised units, some researchers have shown no performance differentials that favor either company-owned units or franchised ones. Bradach's (1998) qualitative study of plural form organizations in the fast food industry revealed no differences between company-owned and franchised units. More recent research finds no significant performance differences (Blair and Lafontaine 2005; Kosová, Lafontaine, and Perrigot 2013) between company-managed and franchisee-managed units. Kosová, Lafontaine, and Perrigot (2013) studied the impact of organizational form (company-owned hotels and franchised hotels) on RevPAR (revenue per available room), occupancy rate and price as indicators of performance. Even though the raw data displayed some differences regarding higher prices and lower occupancy rates in franchised hotels compared to company-owned hotels, they found neither statistically nor economically significant differences in terms of performance according to the two organizational forms. They found that by endogenizing the choice of organizational form, the resulting differences between company-owned hotels and franchised hotels become statistically insignificant. These researchers conclude that a franchisor decides whether to franchise or own a hotel on the basis of the hotel's conditions and market characteristics, and therefore consistent results between the two organizational forms arise. This research supports work examining the chain governance (Barthélemy 2008; Combs and Ketchen 1999b; Yin and Zajac 2004). However, differences in performance at the unit level may exist if an organizational form is constricted by policies or institutional features. 
In conclusion, the evidence remains mixed. Some researchers have found that performance differences exist while others have found no impact of organizational form on unit performance. Proposed benefits of franchising include greater access to capital and incentivizing of local operators. Franchising allows for rapid expansion over a large geographic span by leveraging the franchisees' asset investment. It also solves the inherent vertical agency issues related to incentivizing unit management. One trade-off related to franchising over corporate-ownership is that monitoring becomes significantly more complex as geographic dispersion increases the distance between unit and corporate headquarters. Such loss of control can lead to free-riding on the brand. Therefore, firms often make the choice to franchise or own by weighting the potential benefits and disadvantages of expansion and control. Our research examines one potential advantage of franchising, the ability to incentivize individual franchisees to monitor their employees. That being said, we do not measure franchisor profitability or related performance measures. Therefore, we cannot rule out potential disadvantages that outweigh this potential benefit, including loss of control. Franchisors may optimize performance at the unit level by selecting the appropriate organizational form (Kosová, Lafontaine, and Perrigot 2013), but differences in satisfaction ratings among properties may still be observed.

\section{Development of Research Hypotheses}

One of the reasons for mixed results regarding the performance of company-owned versus franchised units is that the measurement of performance may be the result of various factors outside the control of the manager of the company-owned unit or the franchisee. Singular financial measures of performance may not capture the various performance measures that distinguish a company-owned from a franchised unit. For example, a unit might perform better due to its prime location but provide lower levels of service. Singular 
measures of financial performance may mask potential differences that exist between company-owned and franchised units.

Given that franchisors are motivated to maximize their own profitability, they may award franchisees less desirable locations while keeping more profitable locations as company-owned units. Oxenfeldt and Kelly (1968) were among the first to highlight the potential of franchisors to opportunistically select high performing locations for corporate ownership or repurchase. Other studies have highlighted the potential of such ownership (Brickley and Dark 1987; Caves and Murphy 1976). Though there remains debate regarding the direction and motivation of corporate-owned units (see Dant, Kaufmann, and Paswan 1992; Dant, Paswan, and Kaufmann 1996), the premise that company-owned units would occupy preferred locations compared to franchised units is supported theoretically. Since some research supports the fact that franchisees are often given less desirable, less profitable locations (Chaudhuri, Ghosh, and Spell 2001), a satisfaction measure related to unit location should be higher for company-owned units than for franchised units. We therefore expect that:

H1: Company-owned units will outperform franchised units on satisfaction measures regarding location.

The success of franchising as a form of distribution in a wide spectrum of industries and market segments is due, in part, to its ability to incentivize independent agents while providing them affiliation with a nationally-recognized or internationally-recognized brand. Franchisees use their affiliation with a national or international brand to attract customers to their local units. In exchange for this right, franchisees pay the franchisor a royalty, often a percentage of total revenue. The franchisor makes money on total revenue while the franchisee works to maximize profitability at the local unit. Therefore, franchise 
arrangements partially solve the inherent problem of motivating unit managers who will reduce their effort (that is, shirk) because their self-interest is not tied directly to the success of the unit. Such incentive structures predict differential performance between companyowned and franchised units. Capital investment by the local franchisee should lead to less shirking as compared to company employees. Prior work supports this vertical agency argument (Beheler, Norton, and Sen 2008; Krueger 1991; Freedman and Kosová forthcoming). As such, franchisees should do a better job than managers of company-owned units in terms of monitoring their employees. On measures such as cleanliness and service, that are directly tied to managerial supervision, franchised units should outperform company-owned units. We therefore expect that:

H2: Franchised units will outperform company-owned units on satisfaction measures regarding cleanliness and service.

Satisfaction may also be affected by individual level variables including the type of customer. Business travelers have been found to place higher value on service than leisure travelers (Kashyap and Bojanic 2000). Business customers are generally more astute and demanding of quality service. Some researchers have argued that more frequent customers have higher expectations and thus are more demanding (Reinartz and Kumar 2002). Other works support the moderating role that expertise plays in customer satisfaction (Andreassen and Lindestad 1998; Chiou and Droge 2006). We therefore expect that:

H3: Business customers will have lower ratings than non-business customers on satisfaction measures.

Business customers with greater product and service expertise should be more accurate judges of service quality. They therefore should be better able to distinguish and 
differentiate between positive and negative service experiences. Research suggests that evaluations become more extreme as familiarity or experience with a product increases (Chaiken and Yates 1985; Judd and Lusk 1984; Peracchio and Tybout 1996). Business travelers generally have more experience related to guest stays than leisure customers, and therefore will be more critical of service-related satisfaction ratings given their higher level of knowledge and expertise regarding hotel evaluation. If, as we have argued, franchised units provide higher levels of service than their company-owned counterparts, then we should observe larger differences between these two kinds of units when business travelers, rather than leisure travelers, rate them. The differences between service ratings for franchised and company-owned hotels should be heightened for business travelers. We therefore expect an interaction between organizational form of the hotel and type of customer on satisfaction.

H4: The type of customer (non-business versus business) will moderate the relationship between organizational form and performance. Business travelers will have higher satisfaction with franchised hotels than company-owned hotels on measures related to service.

\section{Methodology}

\section{Data}

The empirical test of the research hypotheses deals with a plural form hotel chain that is part of a large European group. This group holds a wide portfolio of hotel brands from budget to luxury and operates 3,500 corporate and franchised hotels in more than 90 countries. The chain under investigation targets both non-business and business customers. The chain targets families with rooms for up to four persons, play areas, and special family offers. At the same time, the chain focuses on business customers with the promise of 
having "a solution to make [one's] business trips run[ning] more smoothly", "tailor-made solutions that guarantee a successful business trip", special business offers, possibilities to organize meetings, etc. The data we use in this study corresponds to all 134 hotels of this chain that are located in one country's domestic market. We focus on the domestic market due to the chain size (about a third of all hotels are located in the domestic market) and because it allows us to control for potential differences in franchise settings that may exist in different countries.

In this empirical study we use a direct measure of customer satisfaction, that is online consumer-generated reviews that appear on TripAdvisor. We choose TripAdvisor for a number of reasons. First, it is the world's largest specialized travel website. It provides numerous booking tools for interested parties and advice from past travelers (TripAdvisor Website, About TripAdvisor, July 2012). TripAdvisor attracts over 74 million visitors per month, offers more than 75 million reviews and has 32 million members. Over fifty new comments are posted every minute. The website operates in 30 countries all over the world and is accessible in 21 languages (TripAdvisor Website, Fact Sheet, July 2012). TripAdvisor provides a large number of online reviews in comparison with other search engines such as expedia.com, hotels.com, HRS.com, priceline.com, etc., and also includes evaluations from the corporate website of the hotel chain under investigation. Second, it displays several different and complementary criteria for customer satisfaction. Third, it provides control variables (information on hotel characteristics and information on customer profiles). Fourth, TripAdvisor has been used in previous research on customer satisfaction in the hotel industry; for instance, Fernández-Barcala, González-Díaz, and Prieto-Rodriguez (2010) for hotel quality appraisal on the Internet in Spain, Briggs, Sutherland, and Drummong (2007) for service quality in the Scottish hotel sector, Cunningham, Smyth, Wu, and Greene (2010) 
for the hotel sector in Ireland and Silveira Chaves, Gomes, and Pedron (2012) in the case of small and medium-sized hotels in Portugal.

We collected information on customer satisfaction regarding the 134 hotels under investigation as well as information on customer profiles. To connect the customer and hotel data, we use hotel name, address and location matching. A software program designed specifically to capture online data collected the review scores and customer profiles from the webpage of each hotel on the TripAdvisor website. Our data consist of 134 hotels matched with 6,348 observations that contain satisfaction ratings and customer profiles.

\section{Variables}

The dependent variables in our linear regression models correspond to the six specific customer satisfaction criteria: value (price/quality ratio), cleanliness, location, rooms, service and sleep quality. Though our hypotheses do not explicitly include all these various measures of satisfaction, we have used them all to provide a robustness check regarding our findings. TripAdvisor asks the customer to assess each of these six criteria on a five-point measurement scale, where one stands for "terrible", two for "poor", three for "average", four for "very good", and five for "excellent".

Regarding the independent variables, the first one of interest is the organizational form of the hotel: company-owned (coded 0) or franchised (coded 1). Among the 134 hotels under investigation, 69.40 percent are company-owned and 30.60 percent are franchised $^{1}$. A total of 4,915 customers out of 6,348 have expressed their satisfaction regarding a company-

\footnotetext{
${ }^{1}$ The three main organizational forms found in the hotel industry are franchising, company-ownership and management contracts (Contractor and Kundu 1998; Kehoe 1996; Kosová, Lafontaine, and Perrigot 2013; Lafontaine, Perrigot, and Wilson 2013). In this specific country of Western Europe, we observe that franchising and company ownership comprise the majority of hotels. Contract management is much less frequently employed. Kosová et al. (2013) noticed the same trend with only $4 \%$ of the hotels under investigation operated under a management contract.
} 
owned hotel, 1,433 in franchised hotels. The second independent variable of interest is the type of customer: non-business (coded 0) or business (coded 1). Among the 6,348 observations, 4,906 are from non-business customers and 1,442 are from business customers. We also include control variables in our analyses. First, we control for hotel characteristics that can influence customer satisfaction: location (in the city center, near a railway station, near an attraction), the number of rooms, and amenities (the availability of the WIFI, the presence of a parking, the presence of a swimming-pool, the presence of a restaurant, the presence of a bar). Second, we control for the customers' gender as this variable has been shown to influence satisfaction ratings (Bryant and Cha 1996; Mittal and Kamakura 2001).

Table 1 displays the mean, standard deviation, minimal and maximal values for hotel characteristics for all the 134 hotels, then for the company-owned hotels, and finally for the franchised hotels. Company-owned hotels and franchised hotels significantly differ only in terms of number of rooms: company-owned hotels (140.22 rooms on average) are significantly larger than franchised hotels $(111.27$ rooms on average $)(p=.057)$. This difference has already been highlighted by Kosová et al. (2013). The standard deviation for the number of rooms in company-owned hotels is 93.65 , indicating that company-owned hotels operate a large range of differently-sized hotels. Regardless of the organizational form of the hotel (company-owned or franchised), almost all hotels offer WIFI, parking and a bar. Most hotels have a restaurant (85.07 percent) but only 63.43 percent have a swimming pool. 


\begin{tabular}{l|c|c|c|c|c|c|c|c|c|c|c|c}
\hline & \multicolumn{3}{|c|}{ All hotels (N=134) } & \multicolumn{3}{c|}{$\begin{array}{c}\text { Company-owned hotels } \\
\text { (N=93) }\end{array}$} & \multicolumn{3}{c|}{ Franchised hotels (N=41) } \\
\hline & Mean & $\begin{array}{l}\text { Std. } \\
\text { Dev. }\end{array}$ & Min & Max & Mean & $\begin{array}{l}\text { Std. } \\
\text { Dev. }\end{array}$ & Min & Max & Mean & $\begin{array}{l}\text { Std. } \\
\text { Dev. }\end{array}$ & Min & Max \\
\hline City center & 0.44 & 0.50 & 0 & 1 & 0.45 & 0.50 & 0 & 1 & 0.41 & 0.50 & 0 & 1 \\
Railway & 0.46 & 0.50 & 0 & 1 & 0.42 & 0.50 & 0 & 1 & 0.56 & 0.50 & 0 & 1 \\
Attraction & 0.04 & 0.21 & 0 & 1 & 0.05 & 0.23 & 0 & 1 & 0.02 & 0.16 & 0 & 1 \\
\# rooms & 131.4 & 81.10 & 50 & 764 & $140 . .2$ & 93.65 & 61 & 764 & 111.3 & 33.15 & 50 & 193 \\
WIFI & 0.98 & 0.15 & 0 & 1 & 0.99 & 0.10 & 1 & 1 & 0.95 & 0.22 & 0 & 1 \\
Parking & 0.963 & 0.19 & 0 & 1 & 0.978 & 0.15 & 1 & 1 & 0.927 & 0.26 & 0 & 1 \\
Swimming- & 0.63 & 0.48 & 0 & 1 & 0.63 & 0.48 & 0 & 1 & 0.63 & 0.49 & 0 & 1 \\
pool & 0.85 & 0.36 & 0 & 1 & 0.85 & 0.36 & 0 & 1 & 0.85 & 0.36 & 0 & 1 \\
Restaurant & 0.89 & 0.12 & 0 & 1 &, 98 &, 146 & 0 & 1 & 1 & 0.00 & 1 & 1 \\
Bar & 0.99 &
\end{tabular}

Table 1: Hotel Characteristics, Descriptive Statistics, by Organizational Form

Table 2 displays the mean, standard deviation, minimal and maximal values for the six criteria of customer satisfaction for all customers, then for customers who have stayed at company-owned hotels, and finally for customers who have stayed at franchised hotels ${ }^{2}$.

\begin{tabular}{l|c|c|c|c|c|c|c|c|c|c|c}
\hline $\begin{array}{c}\text { Satisfaction } \\
\text { criteria }\end{array}$ & \multicolumn{4}{|c|}{ All customers } & \multicolumn{2}{c|}{$\begin{array}{c}\text { Customers who have } \\
\text { stayed at company- } \\
\text { owned hotels }\end{array}$} & \multicolumn{3}{c}{$\begin{array}{c}\text { Customers who have } \\
\text { stayed at franchised } \\
\text { hotels }\end{array}$} \\
\hline & $\mathrm{N}$ & Mean & $\begin{array}{c}\text { Std. } \\
\text { Dev }\end{array}$ & Min & Max & N & Mean & $\begin{array}{c}\text { Std. } \\
\text { Dev. }\end{array}$ & N & Mean & $\begin{array}{c}\text { Std. } \\
\text { Dev. }\end{array}$ \\
\hline Value & 6,115 & 3.69 & 1.068 & 1 & 5 & 4,732 & 3.68 & 1.084 & 1,383 & 3.74 & 1.014 \\
Location & 5,270 & 3.88 & 1.017 & 1 & 5 & 4,108 & 3.91 & 1.033 & 1,162 & 3.80 & 0.955 \\
Sleep quality & 4,590 & 3.97 & 0.978 & 1 & 5 & 3,488 & 3.94 & 0.993 & 1,102 & 4.07 & 0.924 \\
Rooms & 5,279 & 3.84 & 0.985 & 1 & 5 & 4,113 & 3.81 & 0.993 & 1,166 & 3.93 & 0.948 \\
Cleanliness & 6,121 & 4.13 & 0.944 & 1 & 5 & 4,737 & 4.11 & 0.953 & 1,384 & 4.20 & 0.910 \\
Service & 6,100 & 3.83 & 1.041 & 1 & 5 & 4,719 & 3.82 & 1.039 & 1,381 & 3.86 & 1.045 \\
\hline
\end{tabular}

Table 2: Customer Satisfaction, Descriptive Statistics, by Organizational Form

Table 3 displays the mean, standard deviation, minimal and maximal values for the six criteria of customer satisfaction for all customers, then for the non-business customers, and finally for the business customers.

\footnotetext{
2 These descriptive analyses are run on varying samples in terms of number of observations given that respondents have not always assessed all satisfaction criteria.
} 


\begin{tabular}{|c|c|c|c|c|c|c|c|c|c|c|c|}
\hline \multirow{2}{*}{$\begin{array}{c}\text { Satisfaction } \\
\text { criteria }\end{array}$} & \multicolumn{5}{|c|}{ All customers } & \multicolumn{3}{|c|}{ Non-business customers } & \multicolumn{3}{|c|}{ Business customers } \\
\hline & $\mathrm{N}$ & Mean & $\begin{array}{l}\text { Std. } \\
\text { Dev }\end{array}$ & Min & Max & $\mathrm{N}$ & Mean & $\begin{array}{l}\text { Std. } \\
\text { Dev. }\end{array}$ & $\mathrm{N}$ & Mean & $\begin{array}{l}\text { Std. } \\
\text { Dev. }\end{array}$ \\
\hline Value & 6,115 & 3.69 & 1.068 & 1 & 5 & 4,717 & 3.80 & 1.044 & 1,398 & 3.35 & 1.077 \\
\hline Location & 5,270 & 3.88 & 1.017 & 1 & 5 & 4,014 & 3.93 & 1.003 & 1,256 & 3.73 & 1.049 \\
\hline Sleep quality & 4,590 & 3.97 & 0.978 & 1 & 5 & 3,505 & 4.02 & 0.970 & 1,085 & 3.84 & 0.990 \\
\hline Rooms & 5,279 & 3.84 & 0.985 & 1 & 5 & 4,007 & 3.88 & 0.976 & 1,272 & 3.69 & 0.999 \\
\hline Cleanliness & 6,121 & 4.13 & 0.944 & 1 & 5 & 4,729 & 4.15 & 0.949 & 1,392 & 4.04 & 0.924 \\
\hline Service & 6,100 & 3.83 & 1.041 & 1 & 5 & 4,714 & 3.87 & 1.032 & 1,386 & 3.70 & 1.060 \\
\hline
\end{tabular}

Table 3: Customer Satisfaction, Descriptive Statistics, by Type of Customer

Before testing our research hypotheses, we checked for multicollinearity. The Variance Inflation Factors (VIFs) were all less than two, thus indicating very little likelihood of any multicollinearity on the parameter estimates (Hair et al. 2009). Hence, we did not foresee multicollinearity as a problem in this dataset.

\section{Results}

We used linear regression models to test our research hypotheses (see Table 4). The independent variables of interest were organizational form (company-owned $=0 /$ franchised $=1$ ), customer type (non-business $=0 /$ business $=1$ ) and the interaction term “organizational form X type of customer". We included the following control variables: customer gender (male / female), hotel location (city center, railway station, attraction), amenities (WIFI, parking, swimming pool, restaurant, bar), and the number of rooms.

First, the organizational form of the hotel has a significant and negative influence on customer satisfaction regarding hotel location $(\mathrm{B}=-.129 ; \mathrm{p}<.001)$. Our data thus support hypothesis 1 (Company-owned units will outperform franchised units on satisfaction measures regarding location). 
Second, regarding hypothesis 2 , we find mixed results. The organizational form of the hotel was not a significant predictor for customer satisfaction regarding service $(p>.10)$ but marginally significant and positive for customer satisfaction regarding cleanliness $(\mathrm{B}=$ $.057 ; \mathrm{p}<.10)$. We therefore conclude that hypothesis 2 is not fully supported.

Third, the type of customer (non-business $=0$; business $=1$ ) has a significant and negative impact on customer satisfaction, regarding all satisfaction criteria: location $(\mathrm{B}=-$ $.186 ; \mathrm{p}<.001)$, service $(\mathrm{B}=-.160 ; \mathrm{p}<.001)$, cleanliness $(\mathrm{B}=-.104 ; \mathrm{p}<.001)$, value $(\mathrm{B}=-$ $.443 ; \mathrm{p}<.001)$, rooms $(\mathrm{B}=-.179 ; \mathrm{p}<.001)$, and sleep quality $(\mathrm{B}=-.168 ; \mathrm{p}<.001)$. Our data therefore supports hypothesis 3 (Business customers will have lower ratings than nonbusiness customers on satisfaction measures).

Finally, we find that the interaction term has a significant and positive impact on customer satisfaction regarding service $(\mathrm{B}=.160 ; \mathrm{p}<.05)$, cleanliness $(\mathrm{B}=.135 ; \mathrm{p}=.05)$, value $(\mathrm{B}=.159 ; \mathrm{p}<.05)$, rooms $(\mathrm{B}=.157 ; \mathrm{p}<.05)$ and sleep quality $(\mathrm{B}=.162 ; \mathrm{p}<.05)$. Business travelers have higher satisfaction with franchised hotels than with company-owned hotels. Our data therefore support hypothesis 4 (The type of customer (non-business versus business) will moderate the relationship between organizational form and customer satisfaction. Business travelers will have higher satisfaction with franchised hotels than company-owned hotels on measures related to service). These results support our argument that there are differences between company-owned hotels and franchised hotels, but these differences can only be recognized by expert evaluators such as business customers. ${ }^{3}$

\footnotetext{
${ }^{3}$ In addition to our regression analysis, we performed a MANCOVA with two fixed factors (customer type: non-business versus business) and hotel organizational form (company-owned versus franchised) to provide a clear comparison between the four different conditions. The results of our MANCOVA corroborate our regression results.
} 


\begin{tabular}{|c|c|c|c|c|c|c|c|c|c|c|c|c|c|c|c|c|c|c|}
\hline & \multicolumn{3}{|c|}{ Location } & \multicolumn{3}{|c|}{ Location } & \multicolumn{3}{|c|}{ Service } & \multicolumn{3}{|c|}{ Service } & \multicolumn{3}{|c|}{ Cleanliness } & \multicolumn{3}{|c|}{ Cleanliness } \\
\hline & B & S. E. & Sig. & B & S. E. & Sig. & B & S. E. & Sig. & B & S. E. & Sig. & B & S. E. & Sig. & B & S. E. & Sig. \\
\hline Type of customer & -.186 & .033 & .000 & -.184 & .037 & .000 & -.160 & .032 & .000 & -195 & .036 & .000 & -.104 & .029 & .000 & -.133 & .033 & .000 \\
\hline Org form & -.129 & .036 & .000 & -.127 & .041 & .002 & -.032 & .034 & .346 & -.069 & .038 & .074 & .057 & .031 & .065 & .026 & .035 & .446 \\
\hline Type X form & & & & -.008 & .080 & .916 & & & & .160 & .077 & .037 & & & & .135 & .070 & .052 \\
\hline Gender & .064 & .029 & .028 & .064 & .029 & .028 & .073 & .028 & .008 & .074 & .028 & .008 & .045 & .025 & .070 & .045 & .025 & .068 \\
\hline City center & .075 & .035 & .035 & .075 & .035 & .035 & .122 & .034 & .000 & .124 & .034 & .000 & .048 & .030 & .114 & .049 & .030 & .108 \\
\hline Railway station & .084 & .032 & .008 & .084 & .032 & .008 & .054 & .030 & .072 & .057 & .030 & .060 & .054 & .027 & .050 & .055 & .027 & .042 \\
\hline Attraction & .289 & .087 & .001 & .289 & .087 & .001 & -.041 & .083 & .619 & -.040 & .083 & .631 & -.072 & .075 & .333 & -.071 & .075 & .341 \\
\hline Number of rooms & -.001 & .000 & .000 & -.001 & .000 & .000 & -.001 & .000 & .000 & -.001 & .000 & .000 & -.001 & .000 & .000 & -.001 & .000 & .000 \\
\hline WIFI & .003 & .107 & .979 & .003 & .107 & .979 & -.127 & .099 & .200 & -.130 & .099 & .190 & -.007 & .090 & .939 & -.009 & .090 & .918 \\
\hline Parking & -.100 & .080 & .213 & -.099 & .080 & .215 & .147 & .077 & .056 & .144 & .077 & .062 & .205 & .069 & .003 & .202 & .069 & .003 \\
\hline Swimming pool & -.253 & .034 & .000 & -.253 & .034 & .000 & .033 & .032 & .310 & .037 & .032 & .257 & -.102 & .029 & .000 & -.099 & .029 & .001 \\
\hline Restaurant & .151 & .042 & .000 & .151 & .042 & .000 & -.020 & .040 & .614 & -.024 & .040 & .549 & -.119 & .036 & .001 & -.122 & .036 & .001 \\
\hline $\begin{array}{l}\text { Bar } \\
\text { Constant }\end{array}$ & $\begin{array}{l}-.173 \\
4.208\end{array}$ & $\begin{array}{l}.133 \\
.193\end{array}$ & $\begin{array}{l}.195 \\
.000\end{array}$ & $\begin{array}{l}-.173 \\
4.207\end{array}$ & $\begin{array}{l}.133 \\
.193\end{array}$ & $\begin{array}{l}.194 \\
.000\end{array}$ & $\begin{array}{c}.305 \\
3.587\end{array}$ & $\begin{array}{l}.127 \\
.183\end{array}$ & $\begin{array}{l}.017 \\
.000\end{array}$ & $\begin{array}{c}.311 \\
3.595\end{array}$ & $\begin{array}{l}.127 \\
.183\end{array}$ & $\begin{array}{l}.015 \\
.000\end{array}$ & $\begin{array}{r}.256 \\
3.891\end{array}$ & $\begin{array}{l}.115 \\
.165\end{array}$ & $\begin{array}{l}.026 \\
.000\end{array}$ & $\begin{array}{c}.261 \\
3.898\end{array}$ & $\begin{array}{l}.115 \\
.165\end{array}$ & $\begin{array}{l}.024 \\
.000\end{array}$ \\
\hline Anova & \multicolumn{3}{|c|}{$16.168(.000)$} & \multicolumn{3}{|c|}{$14.922(.000)$} & \multicolumn{3}{|c|}{$11.573(.000)$} & \multicolumn{3}{|c|}{$11.023(.000)$} & \multicolumn{3}{|c|}{$14.598(.000)$} & \multicolumn{3}{|c|}{$13.771(.000)$} \\
\hline $\mathrm{R}^{2}$ & \multicolumn{3}{|c|}{3.6} & \multicolumn{3}{|c|}{3.6} & \multicolumn{3}{|c|}{2.2} & \multicolumn{3}{|c|}{2.3} & \multicolumn{3}{|c|}{2.8} & \multicolumn{3}{|c|}{2.9} \\
\hline Adjusted $\mathrm{R}^{2}$ & \multicolumn{3}{|c|}{3.4} & \multicolumn{3}{|c|}{3.3} & \multicolumn{3}{|c|}{2.0} & \multicolumn{3}{|c|}{2.1} & \multicolumn{3}{|c|}{2.6} & \multicolumn{3}{|c|}{2.7} \\
\hline
\end{tabular}

Table 4: Results of the regression models 


\begin{tabular}{|c|c|c|c|c|c|c|c|c|c|c|c|c|c|c|c|c|c|c|}
\hline & \multicolumn{3}{|c|}{ Value } & \multicolumn{3}{|c|}{ Value } & \multicolumn{3}{|c|}{ Rooms } & \multicolumn{3}{|c|}{ Rooms } & \multicolumn{3}{|c|}{ Sleep quality } & \multicolumn{3}{|c|}{ Sleep Quality } \\
\hline & $\mathrm{B}$ & S. E. & Sig. & $\mathrm{B}$ & S. E. & Sig. & $\mathrm{B}$ & S. E. & Sig. & B & S. E. & Sig. & B & S. E. & Sig. & B & S. E. & Sig. \\
\hline Type of customer & -.443 & .032 & .000 & -.477 & .036 & .000 & -.179 & .031 & .000 & -.212 & .035 & .000 & -.168 & .034 & .000 & -.205 & .039 & .000 \\
\hline Org form & -.008 & .034 & .815 & -.044 & .039 & .250 & .107 & .035 & .002 & .069 & .039 & .078 & .094 & .036 & .010 & .056 & .041 & .169 \\
\hline Type X form & & & & .159 & .077 & .039 & & & & .157 & .076 & .038 & & & & .162 & .081 & .046 \\
\hline Gender & .062 & .028 & .026 & .062 & .028 & .025 & .055 & .028 & .046 & .055 & .028 & .045 & .035 & .030 & .244 & .036 & .030 & .231 \\
\hline City center & .014 & .034 & .681 & .015 & .034 & .651 & .065 & .034 & .052 & .067 & .034 & .047 & .013 & .036 & .715 & .015 & .036 & .681 \\
\hline Railway station & .005 & .030 & .881 & .007 & .030 & .822 & .037 & .030 & .220 & .039 & .030 & .192 & .036 & .033 & .282 & .038 & .033 & .250 \\
\hline Attraction & -.094 & .083 & .259 & -.093 & .083 & .267 & -.022 & .084 & .789 & -.021 & .083 & .799 & .080 & .089 & .371 & .078 & .089 & .377 \\
\hline Number of rooms & -.001 & .000 & .000 & -.001 & .000 & .000 & -.001 & .000 & .000 & -.001 & .000 & .000 & .000 & .000 & .000 & .000 & .000 & .000 \\
\hline WIFI & -.042 & .099 & .673 & -.045 & .099 & .653 & -.016 & .102 & .877 & -.018 & .102 & .858 & -.041 & .105 & .694 & -.044 & .105 & .678 \\
\hline Parking & .133 & .077 & .085 & .129 & .077 & .095 & .368 & .076 & .000 & .363 & .076 & .000 & .051 & .085 & .545 & .048 & .085 & .568 \\
\hline Swimming pool & -.036 & .032 & .263 & -.032 & .032 & .317 & -.105 & .032 & .001 & -.101 & .032 & .002 & -.062 & .035 & .079 & -.059 & .035 & .095 \\
\hline Restaurant & -.293 & .040 & .000 & -.297 & .040 & .000 & -.387 & .040 & .000 & -.392 & .040 & .000 & -.134 & .043 & .002 & -.138 & .044 & .002 \\
\hline $\begin{array}{l}\text { Bar } \\
\text { Constant }\end{array}$ & $\begin{array}{r}.531 \\
3.545\end{array}$ & $\begin{array}{l}.129 \\
.185\end{array}$ & $\begin{array}{l}.000 \\
.000\end{array}$ & $\begin{array}{r}.537 \\
3.554\end{array}$ & $\begin{array}{l}.129 \\
.185\end{array}$ & $\begin{array}{l}.000 \\
.000\end{array}$ & $\begin{array}{r}.343 \\
3.571\end{array}$ & $\begin{array}{l}.127 \\
.184\end{array}$ & $\begin{array}{l}.007 \\
.000\end{array}$ & $\begin{array}{r}.349 \\
3.581\end{array}$ & $\begin{array}{l}.127 \\
.184\end{array}$ & $\begin{array}{l}.006 \\
.000\end{array}$ & $\begin{array}{r}.327 \\
3.830\end{array}$ & $\begin{array}{l}.142 \\
.201\end{array}$ & $\begin{array}{l}.022 \\
.000\end{array}$ & $\begin{array}{r}.330 \\
3.841\end{array}$ & $\begin{array}{l}.142 \\
.201\end{array}$ & $\begin{array}{l}.021 \\
.000\end{array}$ \\
\hline Anova & \multicolumn{3}{|c|}{$36.963(.000)$} & \multicolumn{3}{|c|}{$34.467(.000)$} & \multicolumn{3}{|c|}{$29.570(.000)$} & \multicolumn{3}{|c|}{$27.643(.000)$} & \multicolumn{3}{|c|}{$8.014(.000)$} & \multicolumn{3}{|c|}{$7.711(.000)$} \\
\hline $\mathrm{R}^{2}$ & \multicolumn{3}{|c|}{6.8} & \multicolumn{3}{|c|}{6.9} & \multicolumn{3}{|c|}{6.3} & \multicolumn{3}{|c|}{6.4} & \multicolumn{3}{|c|}{2.1} & \multicolumn{3}{|c|}{2.2} \\
\hline Adjusted $\mathrm{R}^{2}$ & \multicolumn{3}{|c|}{6.6} & \multicolumn{3}{|c|}{6.7} & \multicolumn{3}{|c|}{6.1} & \multicolumn{3}{|c|}{6.2} & \multicolumn{3}{|c|}{1.8} & \multicolumn{3}{|c|}{1.9} \\
\hline
\end{tabular}

Table 4: Results of the regression models (continued) 


\section{Discussion}

\section{Summary of Findings}

In the franchising literature, and also in the development and the management of franchise chains, the focus is often solely on the franchisor/franchisee relationship. With such a focus, it is easy to forget that customers are in fact at the heart of the business and it is this relationship that must also be considered, analyzed and improved. Recently, researchers have underlined the need to focus on these customers in franchise-based businesses (Dant, Grünhagen, and Windsperger 2011). One approach - which we have taken in this study - is to consider customer satisfaction.

Our findings related to customer satisfaction have important implications for the service sector in general, and the hotel sector in particular. First of all, we find that customers are more satisfied with the location of company-owned units than with the location of franchised units. This supports the theoretical argument that franchisors keep the best locations for themselves (Oxenfeldt and Kelly 1968). However, other arguments are also plausible. For instance, from a resource perspective, franchisors may have the needed capital to invest in and manage companyowned hotels in famous and attractive locations while this option may not be available to franchisees.

Regarding our results related to the impact of the organizational form on customer satisfaction regarding service and cleanliness, our results were marginal and did not fully support our hypotheses. We find a main effect of franchised units outperforming company-owned units on satisfaction measures regarding cleanliness but not service. These mixed results, in 
conjunction with our significant interactions related to type of customer, demonstrate that all customers may not evaluate all hotels and types of properties in the same manner.

We find that business customers are globally less satisfied than non-business customers; and this is true for all satisfaction measures. This finding is of great interest when we consider that many hotel chains specifically target business customers. Several factors, such as frequency of visits, experience, knowledge and greater points of comparison, may lead to more demanding customers and provide an explanation for why business customers are usually less satisfied.

Finally, we find that the type of customer (non-business versus business) moderates the relationship between organizational form and customer satisfaction. Business travelers have higher satisfaction with franchised hotels than company-owned hotels on satisfaction measures related to service. For the same reasons mentioned above (frequency of visits, experience, knowledge), these business customers may appreciate their stay at franchised hotels, in which the overall guest experience can be more customized or localized due to the fact that the franchisee is an independent small business owner (Kaufmann and Eroglu 1999). Alternatively, business travelers may be better evaluators of quality and therefore more astute at differentiating between franchised and company-owned properties.

\section{Contributions to research}

Our research contributes to the literature on plural form in franchising. We show that when focusing on business customers alone, who we assume have greater expertise in terms of hotel evaluation, the differences between company-owned hotels and franchised hotels are significant in terms of customer satisfaction. This significant interaction effect involving the organizational form of the hotel (company-owned versus franchised) and the type of customer 
(non-business versus business) also contributes to a stream of research examining the relationship between individual level variables such as expertise (Anderson, Pearo, and Widener 2008; Czellar 2003; Jamal and Anastasiadou 2009; Reinartz and Kumar 2002; Walsh, Evanschitzky, and Wunderlich 2008) and customer attitudes and behaviors.

Our paper also draws on the literature examining franchising in the hospitality sector. Many authors have explored specific aspects of franchising in the context of hotel chains. For instance, Botti, Briec, and Cliquet (2009) and Perrigot, Cliquet, and Piot-Lepetit (2009) analyzed the efficiency of hotel chains with a specific attention given to the plural form. Brookes and Roper (2012) were also interested in plural form in the case of international hotel chains. Chen and Dimou (2005) and Alon, Ni, and Wang (2012) explored the internationalization strategy of franchisors in the hotel industry. Other researchers studied governance structures (Dahlstrom et al. 2009) or quality (Michael 2000) in the hotel industry. Our research, with its focus on customer satisfaction within a hotel chain, enlarges this stream of literature.

We also examine franchising from the view of a consumer, answering the call for more research focusing on new perspectives in franchising. As discussed by Dant, Grünhagen, and Windsperger (2011 p. 254), "there continues to be a virtual absence of examining the franchising phenomenon from the perspective of its customers." Most franchising research is based on empirical studies conducted from a franchisor perspective (Cochet, Dormann, and Ehrmann 2008; El Akremi, Perrigot, and Piot-Lepetit forthcoming; Solis-Rodriguez and González-Díaz 2012). Specifically in the case of the plural form, most authors have adopted a franchisor perspective, underscoring the synergies created by the coexistence of company-owned units and franchised units within the same chain (Bradach 1997; Meiseberg 2012). Few authors have used a franchisee perspective (Perrigot and Herrbach 2012). This paper responds to the call for new 
perspectives in franchising and extends the work on satisfaction within franchised chains by Mellewigt, Ehrmann, and Decker (2011) who focused on satisfaction of franchisees and employee-managers.

Lastly, our empirical study deals with the European market. The selection of this specific market which represents a dynamic franchising sector is consistent with the recommendations issued by Dant (2008) and Dant, Perrigot, and Cliquet (2008) who emphasized the importance of studying franchising issues in markets outside the US. Most empirical studies dealing with Anglo-Saxon markets, mainly the US and Australia, take a predominantly mono-cultural view towards franchising research. Recently, research has focused on franchising in other markets; for instance, France (Perrigot, Oxibar, and Dejean forthcoming; Perrigot et al. 2012) Germany (Meiseberg 2012; Mellewigt, Ehrmann, and Decker 2011) and Spain (González-Díaz and SolisRodriguez 2012; Solis-Rodriguez and González-Díaz 2012). We contribute to this body of work.

\section{Contributions to practice}

This research has some implications for practitioners, specifically for franchisors in the hotel sector as well as franchisees and managers of company-owned hotels. First, our work contributes to a research examining the potential of online reviews as one tool companies can use in a program for continuous improvement (Fernández-Barcala, González-Díaz, and PrietoRodriguez 2010). Taking into consideration customer feedback from websites such as TripAdvisor, hotel practitioners can better assess the different components of customer satisfaction. In the specific case of a plural form chain, customer ratings available on TripAdvisor can serve as a tool for internal benchmarking. We observe that business customers 
are more satisfied in franchised hotels than in company-owned hotels. Specific training programs can then be organized for both franchisees and company-owned hotel managers, with franchisees sharing their best practices and giving tips to managers of company-owned hotels.

Second, the results of the empirical study show that the satisfaction levels vary according to the type of customers: non-business customers versus business customers. On average, business customers are less satisfied than non-business customers. Non-business customers do not have the same experience and knowledge, nor the same frequency of visits, and thus are less critical than business customers. Hotel franchisors looking to target and attract business customers might be better served by relying on franchisees that can better localize their offerings.

Third, for the plural form chain under investigation, customers are more satisfied with the location of the company-owned hotels than with the location of the franchised hotels. This is consistent with previous literature. For instance, Chaudhuri, Ghosh, and Spell (2001) explained that franchisors maintain the most desirable locations as company-owned units, and give the less lucrative locations to the franchisees. This can raise some issues within the chain. Perrigot and Herrbach (2012) recently explained that "some franchisees suspect that managers of the company-owned units are privileged by the franchisor or that inequalities between them and managers exist concerning assortment, supply, communication and advertising." Internal communication has to be managed within the chain in such a way that franchisees do not feel as though there is any location favoritism regarding company-owned hotels.

\section{Limitations and tracks for future research}


This research has some limitations that future research could address. First, the empirical study involves only one chain, and the hotels composing the sample are all located in one domestic market. While the focus on a single chain in a single country is a way to control external effects, it limits the external validity of our findings. Future work should examine larger samples incorporating multiple chains and multiple countries as undertaken by academics that have conducted multi-country studies of franchising issues (Azevedo and Silva 2007; Dunning, Pak, and Beldona 2007; Perrigot, López-Fernández, and Eroglu 2013). Such comparisons have highlighted significant differences in the strategies developed by franchisors of different countries. In particular, Dant, Perrigot and Cliquet (2008) indicated that US franchisors rely more heavily on franchising (9.45 percent company-owned units) than their French counterparts (36.17 percent).

Secondly, there are obviously tradeoffs that corporations make in relation to outsourcing the service of their customers (franchising) and providing this service with corporate employees. Access to capital (resource scarcity) and vertical agency issues (agency theory) are two theoretical views used to support the widespread use of the franchise organizational form. Therefore, firms often make the choice to franchise or own by weighing the potential benefits and disadvantages of expansion and control. Our research quantifies potential advantages of franchised hotels (versus company-owned hotels) in terms of customer satisfaction. But we make no claim about hotel financial performance. As we do not measure chain profitability or other performance measures at the chain level, we cannot rule out any potential advantages that outweigh the potential benefit of high satisfaction. When examining firm performance OLS regression may not be an appropriate analysis due to endogeneity issues (Kosová, Lafontaine, and Perrigot 2013). 
Third, there are some issues with using online satisfaction ratings. These ratings suffer from self-selection bias and therefore may contain highly-polarized satisfaction scores. Satisfaction scores may also be influenced by salient reference scores that are visible to the customer. However, given that these effects should be similar across different types of hotels and types of travelers, we have no reason to suspect that our results are biased.

Fourth, the cross-sectional approach used in this paper does not capture all the dynamics of customer satisfaction. Longitudinal data analysis could be used to provide a description of the evolution of customer satisfaction in this hotel chain; for instance taking into consideration customer loyalty to the brand and their loyalty to the hotel. Future research could also utilize additional data sources, such as questionnaire-based surveys, to measure customer satisfaction over time.

Lastly, the explanatory power of the linear regression models remain low and other determinants of customer satisfaction should be explored. A questionnaire-based survey might be helpful in measuring customer profiles in greater detail. 


\section{References}

Alon, Ilan, Liqiang Ni, and Youcheng Wang (2012), "Examining the determinants of hotel chain expansion through international franchising," International Journal of Hospitality Management, 31(2), 37986.

Anderson, Evan E (1984), "The growth and performance of franchise systems: company versus franchisee ownership," Journal of Economics and Business, 36(4), 421-31.

Anderson, Shannon, Lisa Klein Pearo, and Sally K Widener (2008), "Drivers of service satisfaction linking customer satisfaction to the service concept and customer characteristics," Journal of Service Research, 10(4), 365-81.

Andreassen, Tor Wallin, and Bodil Lindestad (1998), "Customer loyalty and complex services: the impact of corporate image on quality, customer satisfaction and loyalty for customers with varying degrees of service expertise," International Journal of Service Industry Management, 9(1), 7-23.

Azevedo, Paulo F, and Vivian LS Silva (2007), "Governance inseparability in franchising: multi-case study in France and Brazil," in Economics and Management of Networks, Springer, 97-115.

Barthélemy, Jérôme (2008), "Opportunism, knowledge, and the performance of franchise chains," Strategic Management Journal, 29(13), 1451-63.

Beheler, Roy L, Seth W Norton, and Kabir C Sen (2008), "A comparison of company owned and franchised fast food outlet performance: insights from health inspection scores," in Strategy and Governance of Networks, Springer, 113-25.

Bergen, Mark, Shantanu Dutta, and Orville C. Walker Jr (1992), "Agency relationships in marketing: A review of the implications and applications of agency and related theories," The Journal of Marketing, 56(3), 1-24.

Blair, Roger D., and Francine Lafontaine (2005), The Economics of Franchising, Cambridge Univ Press.

Botti, Laurent, Walter Briec, and Gérard Cliquet (2009), "Plural forms versus franchise and companyowned systems: a DEA approach of hotel chain performance," Omega, 37(3), 566-78.

Bradach, Jeffrey L. (1997), "Using the plural form in the management of restaurant chains," Administrative Science Quarterly, 276-303.

-- (1998), Franchise organizations, Harvard Business Press.

Bradach, Jeffrey L., and R. G. Eccles (1989), "Price, authority, and trust: From ideal types to plural forms," Annual Review of Sociology, 15(1), 97-118.

Brand, Maryse J., and Evelien P. M. Croonen (2010), "Franchised and Small, the Most Beautiful of All; HRM and Performance in Plural Systems," Journal of Small Business Management, 48(4), 60526.

Brickley, James A., F. H. Dark, and M. S. Weisbach (1991), “An agency perspective on franchising," Financial Management, 20(1), 27-35.

Brickley, James A., and Frederick H. Dark (1987), "The Choice of Organizational Form: The Case of Franchising," Journal of Financial Economics, 18(2), 401-20.

Briggs, Senga, Jean Sutherland, and Siobhan Drummond (2007), "Are hotels serving quality? An exploratory study of service quality in the Scottish hotel sector," Tourism Management, 28(4), 1006-19.

Brookes, Maureen, and Angela Roper (2012), "Realising plural-form benefits in international hotel chains," Tourism Management, 33(3), 580-91.

Bryant, Barbara Everitt, and Jaesung Cha (1996), "Crossing the threshold: Some customers are harder to please than others, so analyze satisfaction scores carefully," Marketing Research, 8, 20-28.

Carney, Mick, and Eric Gedajlovic (1991), "Vertical integration in franchise systems: agency theory and resource explanations," Strategic Management Journal, 12(8), 607-29. 
Castrogiovanni, Gary J, James G Combs, and Robert T Justis (2006), "Resource Scarcity and Agency Theory Predictions Concerning the Continued Use of Franchising in Multi-outlet Networks," Journal of Small Business Management, 44(1), 27-44.

Caves, Richard E., and William F. Murphy II (1976), "Franchising: Firms, markets, and intangible assets," Southern Economic Journal, 42(4), 572-86.

Chaiken, Shelly, and Suzanne Yates (1985), "Affective-cognitive consistency and thought-induced attitude polarization.," Journal of Personality and Social Psychology, 49(6), 1470.

Chaudhuri, Ananish, Parikshit Ghosh, and Chester Spell (2001), "A location based theory of franchising," Journal of Business and Economics Studies, 7(1), 54-67.

Chaves, Marcirio Silveira, Rodrigo Gomes, and Cristiane Pedron (2012), "Analysing reviews in the Web 2.0: Small and medium hotels in Portugal," Tourism Management, 33(5), 1286-87.

Chen, Jean Jinghan, and Irini Dimou (2005), "Expansion strategy of international hotel firms," Journal of Business Research, 58(12), 1730-40.

Chiou, Jyh-Shen, and Cornelia Droge (2006), "Service quality, trust, specific asset investment, and expertise: direct and indirect effects in a satisfaction-loyalty framework," Journal of the Academy of Marketing Science, 34(4), 613-27.

Cliquet, Gérard, and Thierry Pénard (2012), "Plural form franchise networks: a test of Bradach's model," Journal of Retailing and Consumer Services, 19(1), 159-67.

Cochet, Olivier, Julian Dormann, and Thomas Ehrmann (2008), "Capitalizing on Franchisee Autonomy: Relational Forms of Governance as Controls in Idiosyncratic Franchise Dyads*," Journal of Small Business Management, 46(1), 50-72.

Combs, James G, and David J Ketchen (1999a), "Can capital scarcity help agency theory explain franchising? Revisting the capital scarcity hypothesis.," Academy of Management Journal, 42(2), 196-207.

- - (1999b), "Can capital scarcity help agency theory explain franchising? Revisting the capital scarcity hypothesis.," Academy of Management Journal, 42(2), 196-207.

- - (2003), "Why do firms use franchising as an entrepreneurial strategy?: A meta-analysis," Journal of Management, 29(3), 443-65.

Czellar, Sandor (2003), "Consumer attitude toward brand extensions: an integrative model and research propositions," International Journal of Research in Marketing, 20(1), 97-115.

Dahlstrom, Robert, Sven A Haugland, Arne Nygaard, and Aksel I Rokkan (2009), "Governance structures in the hotel industry," Journal of Business Research, 62(8), 841-47.

Dant, Rajiv P, Marko Grünhagen, and Josef Windsperger (2011), "Franchising research frontiers for the twenty-first century," Journal of Retailing, 87(3), 253-68.

Dant, Rajiv P, Rozenn Perrigot, and Gérard Cliquet (2008), "A cross-cultural comparison of the plural forms in franchise networks: united states, france, and brazil*," Journal of Small Business Management, 46(2), 286-311.

Dant, Rajiv P. (2008), "A futuristic research agenda for the field of franchising," Journal of Small Business Management, 46(1), 91-98.

Dant, Rajiv P., P. J. Kaufmann, and A. K. Paswan (1992), "Ownership redirection in franchised channels," Journal of Public Policy \& Marketing, 33-44.

Dant, Rajiv P., A. K. Paswan, and Patrick J Kaufmann (1996), "What we know about ownership redirection in franchising: A meta-analysis," Journal of Retailing, 72(4), 429-44.

Dunning, John H, Yong Suhk Pak, and Sam Beldona (2007), "Foreign ownership strategies of UK and US international franchisors: An exploratory application of Dunning's envelope paradigm," International Business Review, 16(5), 531-48. 
El Akremi, Assâad, R. Perrigot, and Isabelle Piot-Lepetit (forthcoming), "Examining the drivers for franchised chains performance through the lens of the dynamic capabilities approach," Journal of Small Business Management.

Elango, B (2007), "Are franchisors with international operations different from those who are domestic market oriented?," Journal of Small Business Management, 45(2), 179-93.

Fernández-Barcala, Marta, Manuel González-Díaz, and Juan Prieto-Rodriguez (2010), "Hotel quality appraisal on the Internet: a market for lemons?," Tourism Economics, 16(2), 345-60.

Fladmoe-Lindquist, Karin, and Laurent L Jacque (1995), "Control modes in international service operations: The propensity to franchise," Management Science, 41(7), 1238-49.

González-Díaz, Manuel, and Vanesa Solis-Rodriguez (2012), "Why do entrepreneurs use franchising as a financial tool? An agency explanation," Journal of Business Venturing, 27(3), 325-41.

Hair, Joseph F., Black, William C., Babin, Barry J., and Anderson, Rolph E. (2009), Multivariate data analysis, Prentice Hall.

Handley, Sean M., and W.C. Jr. Benton (2012), "The influence of exchange hazards and power on opportunism in outsourcing relationships," Journal of Operations Management, 30(1), 55-68.

Jamal, Ahmad, and Kyriaki Anastasiadou (2009), "Investigating the effects of service quality dimensions and expertise on loyalty," European Journal of Marketing, 43(3/4), 398-420.

Jensen, Michael C, and William H Meckling (1976), "Theory of the firm: Managerial behavior, agency costs and ownership structure," Journal of financial economics, 3(4), 305-60.

Jin, Ginger Zhe, and Phillip Leslie (2009), "Reputational incentives for restaurant hygiene," American Economic Journal: Microeconomics, 237-67.

Judd, Charles M, and Cynthia M Lusk (1984), "Knowledge structures and evaluative judgments: Effects of structural variables on judgmental extremity.," Journal of Personality and Social Psychology, 46(6), 1193.

Kashyap, Rajiv, and David C Bojanic (2000), "A structural analysis of value, quality, and price perceptions of business and leisure travelers," Journal of Travel Research, 39(1), 45-51.

Kaufmann, Patrick J., and Sevgin Eroglu (1999), "Standardization and adaptation in business format franchising," Journal of Business Venturing, 14(1), 69-85.

Kehoe, Michael R (1996), "Franchising, agency problems, and the cost of capital," Applied Economics, 28(11), 1485-93.

Kosová, Renáta, and Francine Lafontaine (2012), "Much ado about chains: A research agenda," International Journal of Industrial Organization, 30(3), 303-8.

Kosová, Renáta, Francine Lafontaine, and Rozenn Perrigot (2013), “Organizational form and performance: evidence from the hotel industry," Review of Economics and Statistics, 95, 130323.

Krueger, Alan B (1991), “Ownership, agency, and wages: An examination of franchising in the fast food industry," The Quarterly Journal of Economics, 106(1), 75-101.

Lafontaine, Francine (1992), "Agency theory and franchising: some empirical results," Rand Journal of Economics, 23(2), 263-83.

Lafontaine, Francine, and Kathryn L. Shaw (2005), "Targeting Managerial Control: Evidence from Franchising," The Rand Journal of Economics, 36(1), 131-50.

Matthew Freedman, and Renáta Kosová (forthcoming), "Agency and compensation: evidence from the hotel industry," Journal of Law, Economics and Organization ,.

Meiseberg, Brinja (2012), "The Prevalence and Performance Impact of Synergies in the Plural Form," Managerial and Decision Economics.

Mellewigt, Thomas, Thomas Ehrmann, and Carolin Decker (2011), "How Does the Franchisor's Choice of Different Control Mechanisms Affect Franchisees' and Employee-Managers' Satisfaction?," Journal of Retailing, 87(3), 320-31. 
Michael, Steven C (2000), "The effect of organizational form on quality: the case of franchising," Journal of Economic Behavior \& Organization, 43(3), 295-318.

Mittal, Vikas, and Wagner A Kamakura (2001), "Satisfaction, repurchase intent, and repurchase behavior: investigating the moderating effect of customer characteristics," Journal of marketing research, 131-42.

O'Neill, John W, Anna S Mattila, and Qu Xiao (2006), "Hotel guest satisfaction and brand performance: The effect of franchising strategy," Journal of Quality Assurance in Hospitality \& Tourism, 7(3), 25-39.

Oxenfeldt, Alfred R., and Anthony O. Kelly (1968), "Will Successful Franchise Systems Ultimately Become Wholly-Owned Chains?," Journal of Retailing, 44(4), 69-83.

Peracchio, Laura A, and Alice M Tybout (1996), "The moderating role of prior knowledge in schemabased product evaluation," Journal of Consumer Research, 177-92.

Perrigot, Rozenn, Gérard Cliquet, and Isabelle Piot-Lepetit (2009), "Plural form chain and efficiency: Insights from the French hotel chains and the DEA methodology," European Management Journal, 27(4), 268-80.

Perrigot, Rozenn, and Olivier Herrbach (2012), "The plural form from the inside: A study of franchisee perception of company-owned outlets within their network," International Journal of Retail \& Distribution Management, 40(7), 544-63.

Perrigot, Rozenn, Manish Kacker, Guy Basset, and Gérard Cliquet (2012), “Antecedents of Early Adoption and Use of Social Media Networks for Stakeholder Communications: Evidence from Franchising*," Journal of Small Business Management, 50(4), 539-65.

Perrigot, Rozenn, Begoña López-Fernández, and Sevgin Eroglu (2013), "Intangible Resources and Plural Form as Drivers of Franchise Internationalization: Examination within a Two-Country Perspective," Journal of Small Business Management.

Perrigot, Rozenn, Bruno Oxibar, and Frédérique Dejean (forthcoming), "Corporate social disclosure in the franchising sector: insights from french franchisors' websites," Journal of Small Business Management.

Perrigot, Rozenn, and Thierry Pénard (2013), "Determinants of e-commerce strategy in franchising: A resource-based view," International Journal of Electronic Commerce, 17(3), 109-30.

Reinartz, Werner, and VISWANATHAN Kumar (2002), "The mismanagement of customer loyalty," Harvard business review, 80(7), 86-95.

Rubin, Paul H. (1978), "The Theory of the Firm and the Structure of the Franchise Contract," Journal of Law and Economics, 21(1), 223-33.

Shane, Scott A. (1996), "Hybrid organizational arrangements and their implications for firm growth and survival: A study of new franchisors.," Academy of Management Journal, 39(1), 216-34.

- - (1998), "Explaining the distribution of franchised and company-owned outlets in franchise systems," Journal of Management, 24(6), 717-39.

Shelton, John P (1967), "Allocative Efficiency vs.' X-Efficiency': Comment," The American Economic Review, 57(5), 1252-58.

Solis-Rodriguez, Vanesa, and Manuel González-Díaz (2012), "How to Design Franchise Contracts: The Role of Contractual Hazards and Experience," Journal of Small Business Management, 50(4), 652-77.

Walsh, Gianfranco, Heiner Evanschitzky, and Maren Wunderlich (2008), "Identification and analysis of moderator variables: investigating the customer satisfaction-loyalty link," European Journal of Marketing, 42(9/10), 977-1004.

Wu, Guangyu, Derek Greene, Barry Smyth, and Pádraig Cunningham (2010), "Distortion as a validation criterion in the identification of suspicious reviews," ACM, 10-13. 
Yin, Xiaoli, and Edward J. Zajac (2004), "The strategy/governance structure fit relationship: Theory and evidence in franchising arrangements," Strategic management journal, 25(4), 365-83. 